\title{
Effect of Potassium Hydroxide (KOH) Pretreatment on Solids Recovery, Delignification and Total Sugars of Cotton Stalk
}

\author{
Premkumari $^{\text {1* }}$, M. Veerangouda ${ }^{1}$, Vijayakumar Palled ${ }^{1}$, M. Anantachar ${ }^{1}$, \\ Sharanagouda Hiregoudar ${ }^{2}$, Nagaraj M. Naik ${ }^{3}$ and R.V. Beladadhi ${ }^{4}$
}

${ }^{1}$ Department of Farm Machinery and Power Engineering, ${ }^{2}$ Department of Processing and Food Engineering, University of Agricultural Sciences, Raichur 584104, Karnataka, India

${ }^{3}$ Pesticide Residue and Food Quality Analysis Laboratory, University of Agricultural Sciences, Raichur 584104, Karnataka, India

${ }^{4}$ Department of Soil Science and Agricultural Chemistry, University of Agricultural Sciences, Raichur 584104, Karnataka, India

*Corresponding author

\section{Keywords}

Cotton stalk, Cellulose, Ethanol, Potassium hydroxide, Pretreatment

\section{Article Info}

Accepted:

18 January 2019

Available Online:

10 February 2019

\section{A B S T R A C T}

Bioethanol is one of the promising alternative fuels to gasoline in the transport sector. Ethanol may be produced either from petroleum products or from biomass. In the world around $80 \%$ of the ethanol produced is still obtained from fermentation and the reminder comes largely by synthesis from the petroleum product ethylene (Tanaka, 2006). Cotton stalks have been regarded as potential sources for cellulosic ethanol production owing to their high cellulose content being almost 37\% (Binod et al., 2012). Hence, there is a need of utilizing available biomass resources for production of ethanol to reach energy demand. Compounding the challenges is the fact that the country lacks mature technologies for ethanol production from lignocellulosic biomass which is by far the most abundant renewable resource that may be exploited (Lynd et al., 2002; Zhang, 2008). The goal of the pretreatment process is to remove lignin and hemicellulose, reduce the crystallinity of cellulose, and increase the porosity of the lignocellulosic materials. This study is aimed at investigating the effect of potassium hydroxide $(\mathrm{KOH})$ on cotton stalks for optimization of pre-treatment conditions on solids recovery, delignification and total sugars. Potassium hydroxide $(\mathrm{KOH})$ pre-treatment was performed at $50{ }^{\circ} \mathrm{C}, 70{ }^{\circ} \mathrm{C}$ with residence times of 6 , 12 , and $24 \mathrm{~h}$ and $120{ }^{\circ} \mathrm{C}$ with residence times of $0.25,0.5$ and $1 \mathrm{~h}$ each. All the temperature-time pretreatment combinations were performed with potassium hydroxide (KOH) concentrations of 1, 2 and 3\%. Solid recoveries, AIL, ASL, total sugars, cellulose and hemicelluloses content after each pretreatment ranged between 49.60-85.04\%, 10.19$23.96 \%, 1.51-1.95 \%, 268.01-419.51$ (mg/g dry biomass), 33.00-53.54\% and 1.17-14.04\% respectively. Maximum lignin reductions at different temperatures were all obtained at the combinations of highest $\mathrm{KOH}$ concentrations and longest treatment times, which indicated a close relationship between pretreatment severity and lignin reduction. 


\section{Introduction}

Currently the world is mostly dependent on fossil fuels for meeting its energy demand and more than $80 \%$ of the total global energy is obtained by burning fossil fuels, of which $58 \%$ alone is consumed by the transport sector. Rapid increase in the consumption of all kinds of fossil fuels due to the growing industrialization and motorization of the world has resulted in fast depletion of these non-renewable fuels. The limited reserves of the fossil fuels have been anticipated to be exhausted by the next 40-50 years and fossil fuels has the contribution to greenhouse gas emissions and global warming that cause climate change, rise in sea level and loss of biodiversity and urban pollution (Anon, 2013). Therefore, it is necessary to find out an alternative energy source for our industrial economies and consumer societies by using renewable, sustainable, efficient and cost effective feedstocks with lesser emission of greenhouse gases, where bioethanol would be an attractive alternative option due to its ease of production.

Ligno cellulosic biomass refers to plant biomass that is composed of cellulose, hemicellulose, and lignin. The carbohydrate polymers (cellulose and hemicelluloses) are tightly bound to the lignin. They have been considered as alternative energy sources because they can capture $\mathrm{CO}_{2}$ during their growth so that their combustion does not generate net $\mathrm{CO}_{2}$. Cellulose and hemicellulose are polysaccharides that can be used for ethanol production, while lignin is a complex aromatic polymer that stiffens and surrounds the fibres of polysaccharides.

Cotton is a major commercial crop grown in almost all the Agro-climatic zones of Karnataka. All the four cultivated species of cotton viz., Gossypium arboreum, $G$. herbaceum, G. barbadense, and G. hirsutum are grown in the state where in Gossypium hirsutum has the major share of the hybrid cotton grown. Cotton stalk is one of the important by products of cotton crop and about 23 million tonnes of cotton plant stalks are generated in India annually. On an average about 2 to 3 tonnes of stalk are generated in one hectare of land. Most of the stalk is treated as waste, though a small part of it $(15 \%)$ is used as fuel. The lignocellulosic nature of cotton stalk favours to use as renewable material for variety of commercial applications. In conventional method, bulk of the stalk is burnt in the fields after the harvest of the cotton crop although it is not desirable since it causes air pollution. Hence, it is required to utilize cotton stalk for ethanol production instead of burning in the field.

The conversion of lingo cellulosic biomass to ethanol is more challenging. The process of ethanol production from lingocellulosic biomass constitutes three stages: (a) pretreatment of biomass to reduce lignin content and cellulose crystallinity, (b) hydrolysis of pretreated biomass for sugar generation, and (c) fermentation of sugars into ethanol.

Pretreatment of biomass has been found to change its macromolecular structure and increase surface area and pore size, making it conducive for hydrolytic enzymes to attach themselves to the carbohydrate matrix for generating sugars, which are subsequently converted to ethanol through bacterial or yeast fermentation. Pretreatment can be divided into three main categories: (a) physical, (b) chemical, and (c) biological. Physical pretreatment processes have proven to be energetically unviable and biological pretreatment methods can be expensive and time consuming. Chemical pretreatment techniques on the other hands have been the most widely studied and alkaline pretreatment in particular has seen considerable success (Vijayakumar et al., 2016). 
Silverstein et al., (2007) investigated chemical pretreatment of cotton stalks and reported that, among four pretreatment methods $\left(\mathrm{NaOH}, \mathrm{H}_{2} \mathrm{SO}_{4}, \mathrm{H}_{2} \mathrm{O}_{2}\right.$, and ozone pretreatments), $\mathrm{NaOH}$ pretreatment resulted in the highest level of delignification $(65.63 \%$ at $2 \% \mathrm{NaOH}, 90 \mathrm{~min}, 121{ }^{\circ} \mathrm{C}$ ) and cellulose conversion $(60.8 \%)$.

Shi et al., (2009) studied the fungus, Phanerochaete chrysosporium, to pretreat cotton stalks with two methods, shallow stationary and agitated cultivation, at three supplemental salt concentrations. Pretreatment efficiencies were compared by evaluating lignin degradation, solid recovery and carbohydrate availability over a 14-day period. Shallow stationary cultivation with no salts gave $20.7 \%$ lignin degradation along with $76.3 \%$ solid recovery and $29.0 \%$ carbohydrate availability. The highest lignin degradation of $33.9 \%$ at a corresponding solid recovery and carbohydrate availability of $67.8 \%$ and $18.4 \%$, respectively, was obtained through agitated cultivation with Modified NREL salts.

Keshav et al., (2016) reported that cotton stalk pretreated to steam explosion in the range $170-200{ }^{\circ} \mathrm{C}$ for $5 \mathrm{~min}$. Steam explosion at $200{ }^{\circ} \mathrm{C}$ and $5 \mathrm{~min}$ led to significant hemicellulose solubilization $(71.90 \pm 0.10 \%)$. Alkaline extraction of steam exploded cotton stalk (SECOH) using 3\% NaOH at room temperature for $6 \mathrm{~h}$ led to $85.07 \pm 1.43 \%$ lignin removal with complete hemicellulose solubilization. Besides, this combined pretreatment allowed a high recovery of the cellulosic fraction from the biomass. Enzymatic saccharification was studied between steam exploded cotton stalk (SECS) and SECOH using different cellulase loadings. SECOH gave a maximum of $785.30 \pm 8.28 \mathrm{mg} / \mathrm{g}$ reducing sugars with saccharification efficiency of $82.13 \pm 0.72 \%$. Subsequently, fermentation of SECOH hydrolysate containing sugars $(68.20 \pm 1.16$ g/l) with Saccharomyces cerevisiae produced $23.17 \pm 0.84 \mathrm{~g} / 1$ ethanol with $0.44 \mathrm{~g} / \mathrm{g}$ yield.

Potassium hydroxide is a relatively less explored pretreatment agent but could potentially be used for lignocellulose pretreatment due to its reported reactivity with carbon nanofibers and carbon nanostructures and its ability to deacetylate biomass.

Keeping this in view, the effect of alkaline pretreatment conditions on delignification and total sugar content of cotton stalks was investigated.

\section{Materials and Methods}

Cotton stalk is selected as raw material in this study for testing its feasibility for production of cellulosic ethanol. The cotton stalks available in the University of Agricultural Sciences, Raichur campus was selected. The cotton stalks were cut into small chips and oven dried at $70^{\circ} \mathrm{C}$ in a forced air oven for 72 $\mathrm{h}$. Then oven dried samples were ground to pass through a $2 \mathrm{~mm}$ sieve in a hammer mill and stored at room temperature in zip-locked plastic bags, and used for further experimentation.

The initial composition of cotton stalk was analyzed using Laboratory Analytical Procedures (LAP) adopted by National Renewable Energy Laboratory (NREL) for the measurement of total solids, acid insoluble lignin (AIL), acid soluble lignin (ASL) and ash (Sluiter et al., 2005a, 2005b; Sluiter et al., 2008). While the structural carbohydrates (cellulose and hemicelluloses) represented by total reducing sugars of biomass was estimated by the 3, 5-dinitrosalycylic acid (DNS) method (Ghose, 1987; Miller, 1959). Whereas, the crude protein, crude fibre and crude fat present in cotton stalk were 
estimated by the AOAC method (AOAC, 2005). Cellulose was estimated by standard cellulose solution methods and hemicellulose was estimated by determining (ADF) acid detergent fibre and (NDF) neutral detergent fibre.

In this experiment, potassium hydroxide $(\mathrm{KOH})$ pretreatment of cotton stalk at different elevated temperatures ranging from 50 to $120{ }^{\circ} \mathrm{C}$ with various combinations of residence times and $\mathrm{KOH}$ concentrations was explored. Pretreatment of cotton stalk samples were performed at 50,70 with residence times of 6,12 , and $24 \mathrm{~h}$ and $120^{\circ} \mathrm{C}$ with residence times of $0.25,0.5$, and $1 \mathrm{~h}$ each. All the temperature-time pretreatment combinations were performed with potassium hydroxide $(\mathrm{KOH})$ concentrations of 1,2 and 3 per cent $(\mathrm{w} / \mathrm{v})$.

Five grams of cotton stalk sample was mixed with $50 \mathrm{ml}$ of $\mathrm{KOH}$ solution in $125 \mathrm{ml}$ bottles using glass rods, and the bottles were sealed before pretreatment and kept in a water bath (Plate 1) and autoclave (Plate 2).

The pretreated samples were filtered through pre-weighed filter paper in vacuum flask using a vacuum pump. The bottles were rinsed with $50 \mathrm{ml}$ DI water to recover the residual solids. All solids accumulated on the filter papers in the filtration set up were quantified by oven drying and considered in solid recovery calculations.

$5 \mathrm{~g}$ of wet biomass was drawn from each pretreated sample and dried at $105{ }^{\circ} \mathrm{C}$ in conventional hot air oven for estimation of solid recovery. A similar amount was placed for vacuum drying at $40{ }^{\circ} \mathrm{C}$ in vacuum oven to obtain samples for estimation of acid insoluble lignin (AIL), acid soluble lignin (ASL), total sugar, cellulose and hemicellulose content to study the effect of pretreatment conditions on cotton stalk. All treatments in this study were conducted in triplicate.

\section{Results and Discussion}

\section{Composition of cotton stalk}

The initial composition of cotton stalk used in this study is presented in Table 1 . The carbohydrate (total reducing sugars) of cotton stalk was estimated to be $58.66 \%$. Cellulose and hemicelluloses were $42.63 \%$ and $16.03 \%$ respectively. Total lignin (including AIL and ASL), which is the major non-carbohydrate component, was determined to be $32.72 \%$, ash and total solids were estimated to be $5.56 \%$ and $92.08 \%$ respectively. The crude fibre, fat and protein of sample were observed to be $49.71 \%, 0.9 \%$ and $1.7 \%$ respectively.

\section{Effect of pretreatment conditions}

Pretreatment conditions had varying effects on solid recovery, acid insoluble lignin and acid soluble lignin, total sugar, cellulose and hemicellulose in the biomass. Intensity of treatment increased with increasing $\mathrm{KOH}$ concentration and treatment temperature.

\section{Solid recovery}

On an average, solid recoveries after pretreatment at different temperature-time combinations using various concentrations of $\mathrm{KOH}$ ranged between 64.85 and $85.04 \%$ at $50^{\circ} \mathrm{C}, 59.13-81.29 \%$ at $70^{\circ} \mathrm{C}$, and 68.59 $49.6 \%$ at $120^{\circ} \mathrm{C}$ (Table 2).

It was observed that the maximum solids of $85.04 \%$ in the sample pretreated at $50{ }^{\circ} \mathrm{C}, 6 \mathrm{~h}$ combination with $1 \% \mathrm{KOH}$, whereas, it was minimum $49.60 \%$ in the sample pretreated with $3 \% \mathrm{KOH}$ at $120^{\circ} \mathrm{C}, 1 \mathrm{~h}$. It was observed that lesser solids were recovered as intensity of the pretreatment increased. 


\section{Acid insoluble lignin}

Acid insoluble lignin after pretreatment at different temperature-time combinations using various concentrations of $\mathrm{KOH}$ ranged between 16.1-23.96\% at $50{ }^{\circ} \mathrm{C}$ (Fig. 1), 14.1$20.25 \%$ at $70{ }^{\circ} \mathrm{C}$ (Fig. 2) and $10.19-16.8 \%$ at $120{ }^{\circ} \mathrm{C}$ (Fig. 3). The maximum acid insoluble lignin of $23.96 \%$ was recorded in the sample pretreated at $50{ }^{\circ} \mathrm{C}, 6 \mathrm{~h}$ combination with $1 \%$ $\mathrm{KOH}$, whereas, it was minimum (10.19\%) in the sample pretreated with $3 \% \mathrm{KOH}$ at 120 ${ }^{\circ} \mathrm{C}, 1 \mathrm{~h}$.

It was observed that increasing pretreatment, a decrease in acid insoluble lignin in all the samples with three concentrations of $\mathrm{KOH}$ loaded at all the temperature-time combinations were recorded.

\section{Acid soluble lignin}

After $\mathrm{KOH}$ pretreatment, acid soluble lignin at different temperature-time combinations using various concentrations of $\mathrm{KOH}$ ranged between $1.54-1.79 \%$ at $50{ }^{\circ} \mathrm{C}, 1.56-1.83 \%$ at $70{ }^{\circ} \mathrm{C}$ and $1.56-1.95 \%$ at $120^{\circ} \mathrm{C}$.

It was observed that acid soluble lignin increased up to $2 \% \mathrm{KOH}$ concentration at higher temperature-time combinations.

\section{Total sugar content}

On an average, total sugar content ranged between 268.01-419.51 mg/g dry biomass (Table 3) after pretreatment at different temperature-time combinations using various concentrations of $\mathrm{KOH}$.

It was observed that when the sample was pretreated with different concentrations of $\mathrm{KOH}$, at 50,70 and $120{ }^{\circ} \mathrm{C}$, the release in sugar increased with increase in acid concentration upto $2 \%(\mathrm{v} / \mathrm{v}) \mathrm{KOH}$ and it declined thereafter.
The maximum sugars of $419.51 \mathrm{mg} / \mathrm{g}$ were released, when the sample was pretreated with $2 \% \mathrm{KOH}$ concentration at $120{ }^{\circ} \mathrm{C}$ for $1 \mathrm{~h}$. Whereas, it was minimum $(268.01 \%)$ in the sample pretreated at $50{ }^{\circ} \mathrm{C}, 6 \mathrm{~h}$ combination with $1 \% \mathrm{KOH}$.

\section{Cellulose content}

The results of cellulose content ranged between $29.02-48.54 \%$ after pretreatment at different temperature-time combinations using various concentrations of $\mathrm{KOH}$ (Table 4).

The maximum cellulose content of $48.54 \%$ was observed in the sample pretreated at 120 ${ }^{\circ} \mathrm{C}, 1 \mathrm{~h}$ combination with $2 \% \mathrm{KOH}$, whereas, it was minimum (29.02\%) in the sample pretreated with $1 \% \mathrm{KOH}$ at $50{ }^{\circ} \mathrm{C}, 6 \mathrm{~h}$.

It was observed that when the sample was pretreated at 50,70 and $120^{\circ} \mathrm{C}$ with different concentrations of $\mathrm{KOH}$, the release in cellulose increased with increase in akali concentration upto $2 \%(\mathrm{v} / \mathrm{v}) \mathrm{KOH}$ and it declined thereafter by increasing concentration.

\section{Hemicellulose content}

Hemicellulose content ranged between 1.17$14.04 \%$ after pretreatment at different temperature-time combinations using various concentrations of $\mathrm{KOH}$.

After $\mathrm{KOH}$ pretreatment, hemicelluloses content ranged between $8.34-14.04 \%$ at $50{ }^{\circ} \mathrm{C}$ (Fig. 4), 4.93-8.96\% at $70{ }^{\circ} \mathrm{C}$ (Fig. 5), and $1.17-5.19 \%$ at $120{ }^{\circ} \mathrm{C}$ (Fig. 6).

The maximum hemicellulose content of $14.04 \%$ was observed in the sample pretreated at $50{ }^{\circ} \mathrm{C}, 6 \mathrm{~h}$ combination with $3 \% \mathrm{KOH}$, whereas, it was minimum $(1.17 \%)$ in the sample pretreated with $2 \% \mathrm{KOH}$ at $120{ }^{\circ} \mathrm{C}, 1$ h. 
Table.1 Composition of cotton stalk

\begin{tabular}{|c|c|c|}
\hline Sl. No. & Component & Dry weight (\%) \\
\hline $\mathbf{1}$ & Total solids & 92.08 \\
\hline $\mathbf{2}$ & Acid insoluble lignin & 30.71 \\
\hline $\mathbf{3}$ & Acid soluble lignin & 2.01 \\
\hline $\mathbf{4}$ & Total sugars & 58.66 \\
\hline $\mathbf{5}$ & Cellulose & 42.63 \\
\hline $\mathbf{6}$ & Hemicellulose & 16.03 \\
\hline $\mathbf{7}$ & Ash & 5.56 \\
\hline $\mathbf{8}$ & Crude fiber & 49.71 \\
\hline $\mathbf{9}$ & Crude fat & 0.9 \\
\hline $\mathbf{1 0}$ & Crude protein & 1.7 \\
\hline
\end{tabular}

Table.2 Effect of potassium hydroxide pretreatment on solids recovery of cotton stalk

\begin{tabular}{|c|c|c|c|c|}
\hline \multirow[t]{3}{*}{ Temperature $\left({ }^{\circ} \mathbf{C}\right)$} & \multirow[t]{3}{*}{ Time, h } & \multirow{2}{*}{\multicolumn{3}{|c|}{$\begin{array}{c}\text { Solids recovery }(\%) \\
\text { KOH concentration }(\%)\end{array}$}} \\
\hline & & & & \\
\hline & & 1 & 2 & 3 \\
\hline \multirow{3}{*}{50} & 6 & 85.04 & 82.89 & 79.36 \\
\hline & 12 & 80.07 & 74.97 & 72.98 \\
\hline & 24 & 79.14 & 68.95 & 64.85 \\
\hline \multirow{3}{*}{70} & 6 & 81.29 & 74.58 & 69.46 \\
\hline & 12 & 78.59 & 73.4 & 66.81 \\
\hline & 24 & 74.89 & 64.85 & 59.13 \\
\hline \multirow{3}{*}{120} & 0.25 & 68.59 & 63.85 & 61.59 \\
\hline & 0.5 & 63.38 & 58.53 & 54.23 \\
\hline & 1 & 59.01 & 51.71 & 49.6 \\
\hline
\end{tabular}

Table.3 Effect of potassium hydroxide $(\mathrm{KOH})$ pretreatment on total sugars of cotton stalk

\begin{tabular}{|c|c|c|c|c|}
\hline \multirow[t]{3}{*}{ Temperature $\left({ }^{\circ} \mathbf{C}\right)$} & \multirow[t]{3}{*}{ Time, h } & \multirow{2}{*}{\multicolumn{3}{|c|}{$\begin{array}{c}\text { Total sugars (mg/g dry biomass) } \\
\text { KOH concentration }(\%)\end{array}$}} \\
\hline & & & & \\
\hline & & 1 & 2 & 3 \\
\hline \multirow{3}{*}{50} & 6 & 268.01 & 303.46 & 293.10 \\
\hline & 12 & 323.16 & 354.71 & 349.64 \\
\hline & 24 & 353.18 & 365.56 & 357.20 \\
\hline \multirow{3}{*}{70} & 6 & 343.78 & 356.11 & 353.60 \\
\hline & 12 & 359.68 & 367.37 & 363.46 \\
\hline & 24 & 363.60 & 373.29 & 367.38 \\
\hline \multirow{3}{*}{120} & 0.25 & 376.98 & 393.47 & 382.63 \\
\hline & 0.5 & 386.99 & 403.84 & 399.69 \\
\hline & 1 & 402.58 & 419.51 & 409.79 \\
\hline
\end{tabular}


Table.4 Effect of potassium hydroxide $(\mathrm{KOH})$ pretreatment on cellulose of cotton stalk

\begin{tabular}{|l|c|c|c|c|}
\hline \multirow{3}{*}{ Temperature $\left({ }^{\circ} \mathbf{C}\right)$} & \multirow{2}{*}{ Time, h } & \multicolumn{3}{|c|}{ Cellulose (\%) } \\
\cline { 2 - 5 } & & \multicolumn{3}{|c|}{ KOH concentration (\%) } \\
\cline { 2 - 5 } & & 1 & 2 & 3 \\
\hline \multirow{3}{*}{$\mathbf{5 0}$} & 6 & 35.02 & 36.91 & 33.00 \\
\hline \multirow{3}{*}{$\mathbf{7 0}$} & 12 & 37.26 & 39.77 & 35.12 \\
\hline & 24 & 38.60 & 40.34 & 36.35 \\
\hline \multirow{3}{*}{$\mathbf{1 2 0}$} & 6 & 39.62 & 41.51 & 37.61 \\
\hline & 12 & 42.61 & 45.98 & 41.67 \\
\hline & 24 & 44.85 & 47.84 & 42.52 \\
\hline & 0.25 & 46.48 & 49.96 & 45.44 \\
\hline & 0.5 & 48.78 & 51.93 & 47.51 \\
\hline & 1 & 50.42 & 53.54 & 49.67 \\
\hline
\end{tabular}

Fig.1 Acid insoluble lignin of cotton stalk pretreated with $1.0-3.0 \% \mathrm{KOH}$ at $50{ }^{\circ} \mathrm{C}$

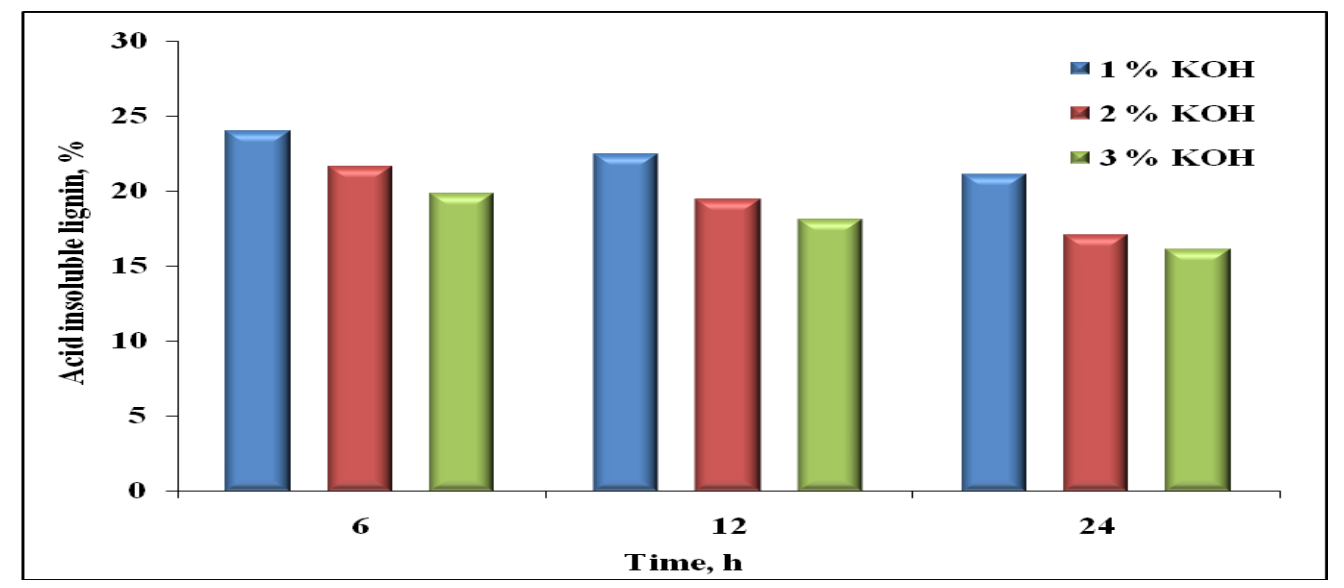

Fig.2 Acid insoluble lignin of cotton stalk pretreated with $1.0-3.0 \% \mathrm{KOH}$ at $70{ }^{\circ} \mathrm{C}$

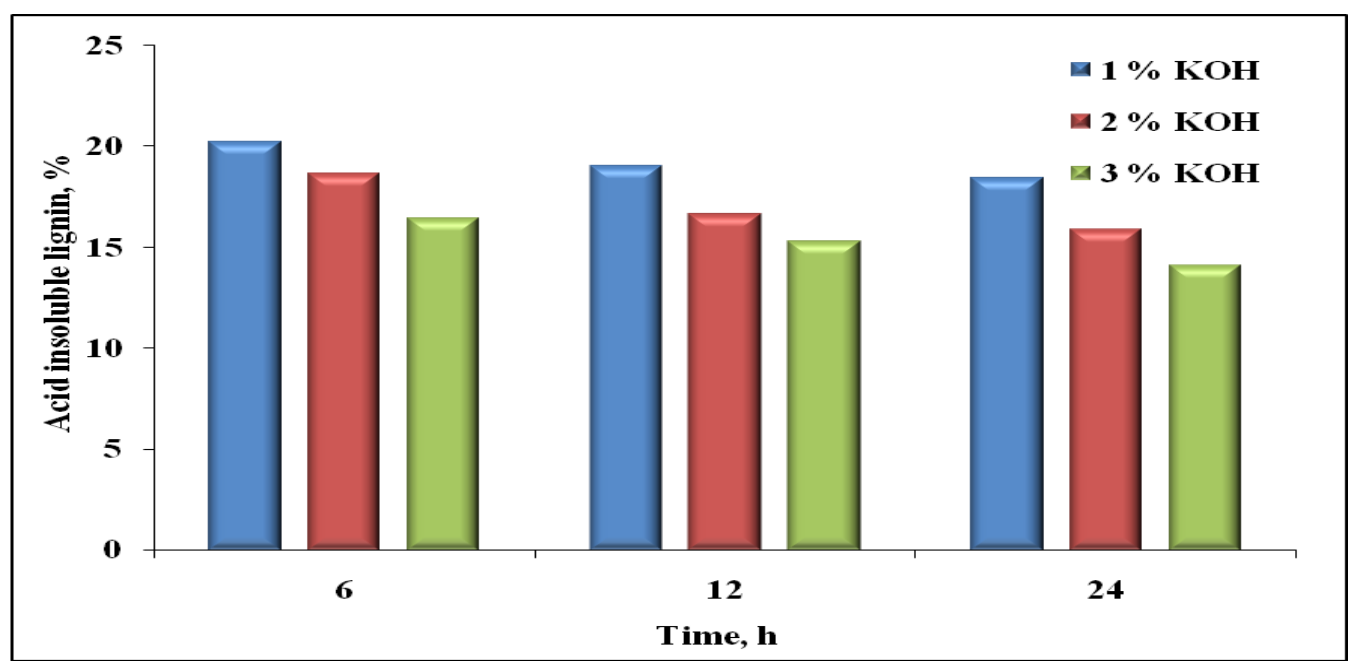


Fig.3 Acid insoluble lignin of cotton stalk pretreated with $1.0-3.0 \% \mathrm{KOH}$ at $120{ }^{\circ} \mathrm{C}$

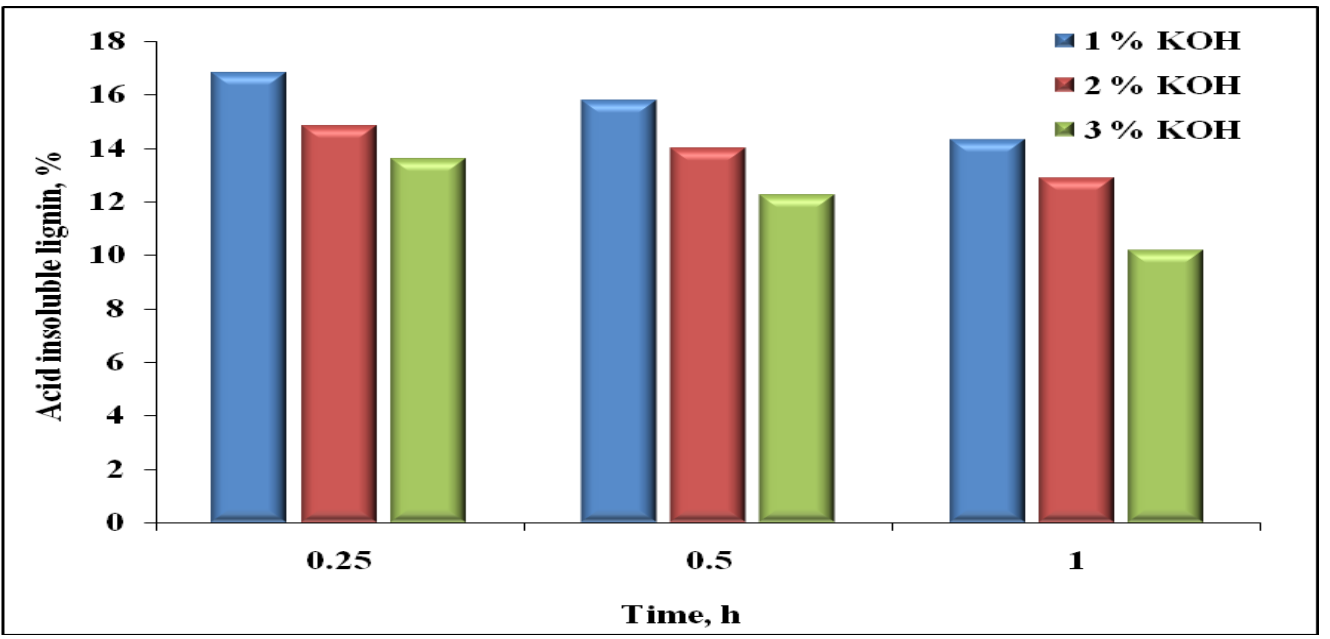

Fig.4 Hemicellulose content of cotton stalk pretreated with $1.0-3.0 \% \mathrm{KOH}$ at $50{ }^{\circ} \mathrm{C}$

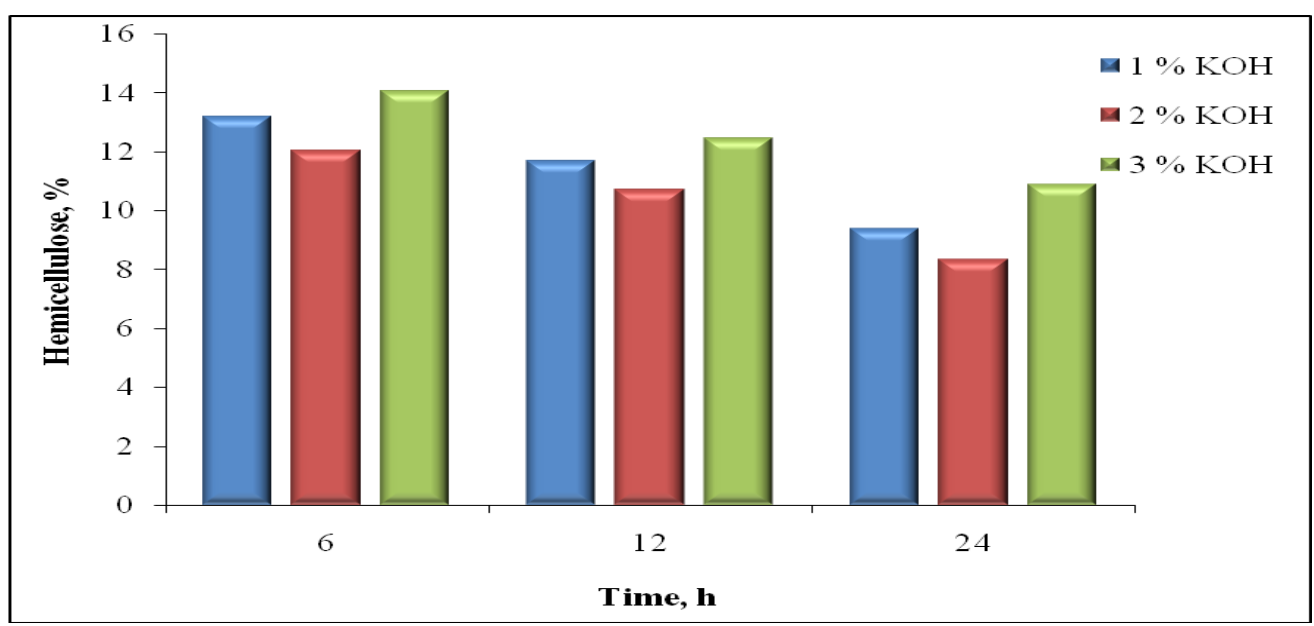

Fig.5 Hemicellulose content of cotton stalk pretreated with $1.0-3.0 \% \mathrm{KOH}$ at $70{ }^{\circ} \mathrm{C}$

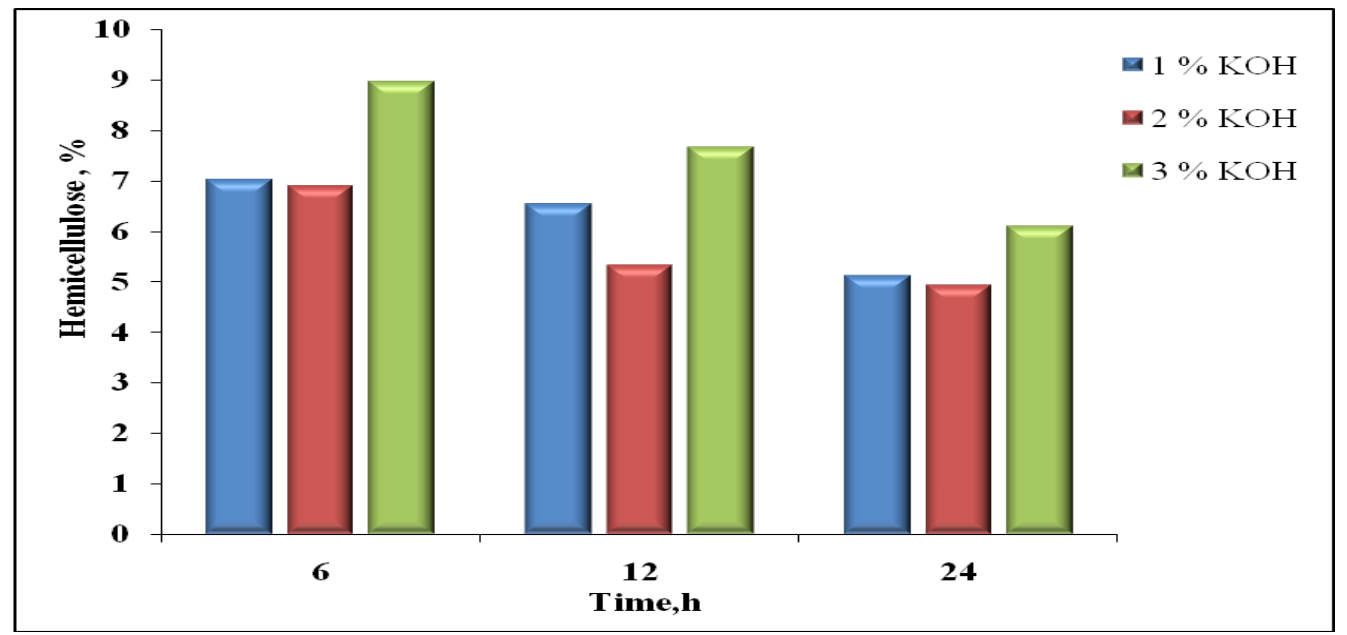


Fig.6 Hemicellulose content of cotton stalk pretreated with $1.0-3.0 \% \mathrm{KOH}$ at $120{ }^{\circ} \mathrm{C}$

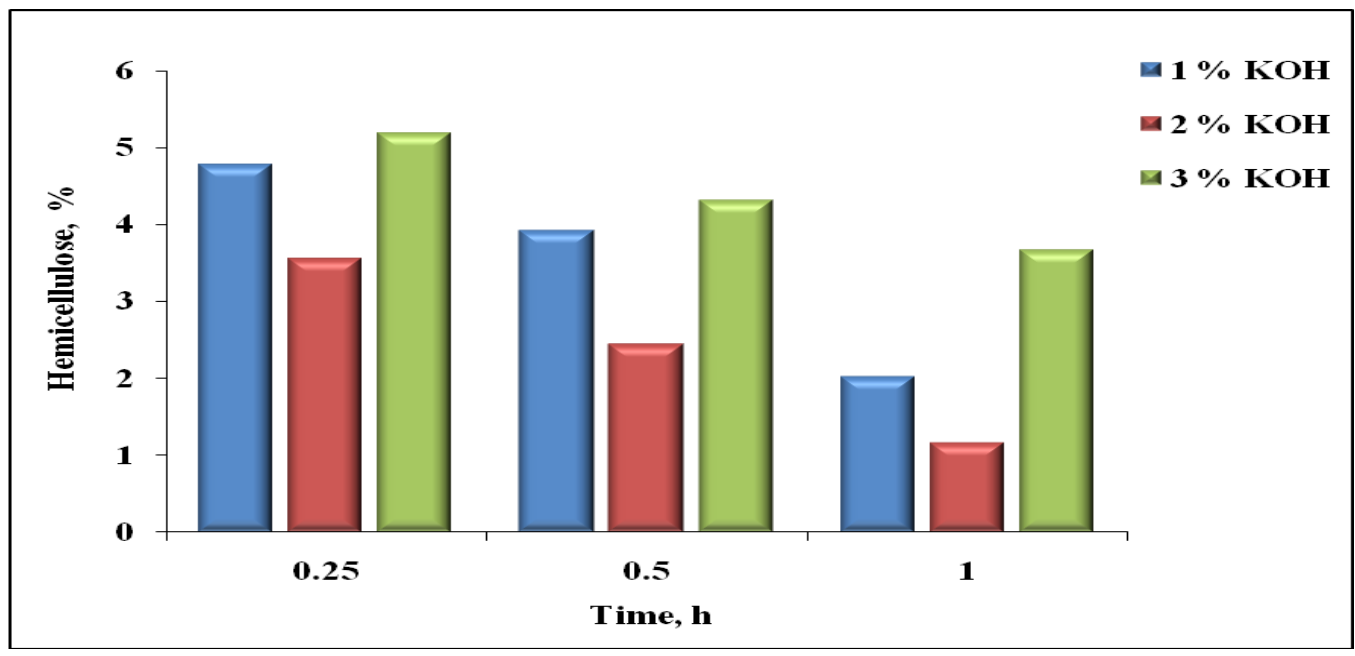

Plate.1 Samples kept in water bath for pretreatment

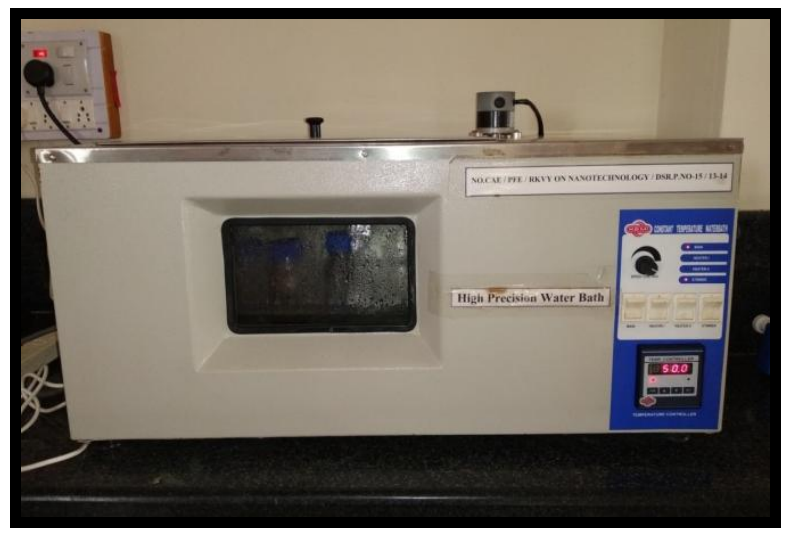

Plate.2 Pretreatment using fully automatic horizontal autoclave

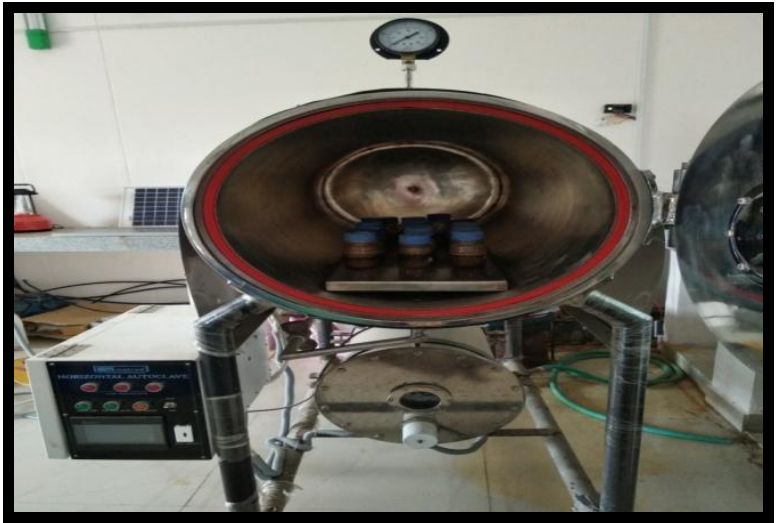


In conclusion, pretreatment of ground cotton stalk with $\mathrm{KOH}$ resulted in high sugar yield with the $2 \% \mathrm{KOH}, 1 \mathrm{~h}, 120{ }^{\circ} \mathrm{C}$ pretreatment indicates that even low concentrations of $\mathrm{KOH}$ can be effective in generating high sugars during hydrolysis. The highest carbohydrate retention of $71.51 \%$ was observed in the sample pretreated at $120{ }^{\circ} \mathrm{C}$ with $2 \% \mathrm{KOH}$ and $1 \mathrm{~h}$. Almost $53.95 \%$ of solids were dissolved at $120{ }^{\circ} \mathrm{C}$ after $1 \mathrm{~h}$ pretreatment with $3 \% \mathrm{KOH}$ concentration. The corresponding maximum lignin reductions of $50.79 \%, 56.91 \%$ for $50,70{ }^{\circ} \mathrm{C}$ at $24 \mathrm{~h}, 3 \% \mathrm{KOH}$ respectively and $68.86 \%$ were obtained at $120{ }^{\circ} \mathrm{C}$ for $1 \mathrm{~h}, 3 \% \mathrm{KOH}$ concentrations. Pretreatment with potassium hydroxide was able to degrade lignin in cotton stalks. Maximum lignin reductions at different temperatures were all obtained at the combinations of highest $\mathrm{KOH}$ concentrations and longest treatment times, which indicated a close relationship between pretreatment severity and lignin reduction.

\section{References}

Alvira, P., Tomas-Pejo, E., Ballesteros, M. and Negro. M. J., 2010, Pretreatment technologies for an efficient bioethanol production based on enzymatic hydrolysis: A review. Bioresour. Technol., 101(13): 48514861.

Amrita, V., Santosh, K. and Jain, P. K., 2011, Key pretreatment technologies on cellulosic ethanol production. $J$. Scientific Res., 55(2): 57-63.

Anonymous, 2003, Report of the committee on development of biofuels. Planning Commission, Government of India. $<$ http://planningcommission.nic.in/rep orts/ genrep / cmtt _ bio. pdf >

AOAC, 2005, Official methods of analysis, $\left(16^{\text {th }}\right.$ Edi), Association of official analytical chemists, Gaithersburg, MD, USA.
Binod, P., Kuttiraja, M., Archana, M., Janu, K. U., Sindhu, R., Sukumaran, R. K. and Pandey, A., 2012, High temperature pretreatment and hydrolysis of cotton stalk for producing sugars for bioethanol production. Fuel, 92(1): 340-345.

Du, S. K., Zhu, X., Wang, H., Zhou, D., Yang, W. and $\mathrm{Xu}, \mathrm{H} ., 2013$, High pressure assist-alkali pretreatment of cotton stalk and physiochemical characterization of biomass, Bioresour. Technol., 148(3): 494-500.

Ghose, T. K., 1987, Measurement of cellulase activities. Pure and Appl. Chem., 59(2): 257-268.

Gurjar, R, M., Shaikh, A, J., Balasubramanya, R, H. and Sreenivasan, S., 2007, Composite boards from cotton stalks. Central Institute for Research on Cotton Technology, Matunga, Mumbai-400 019.

Jiang, W., Chang, S., Hongqiang, L., Oleskowicz-Popiel, P. and $\mathrm{Xu}, \mathrm{J}$., 2015, Liquid hot water pretreatment on different parts of cotton stalk to facilitate ethanol production. Bioresour. Technol., 176(1): 175-180.

Kaura, U., Oberoia, H, S., Bhargavb, V., Sharma, R, S. and Dhaliwala, S, S., 2012, Ethanol production from alkaliand ozonetreated cotton stalks using thermotolerant Pichia kudriavzevii HOP1. Ind. Crops and Products. 37(1): 219-226.

Keshav, P. K., Naseeruddin, S. L. and Rao, V., 2016, Improved enzymatic saccharification of steam exploded cotton stalk using alkaline extraction and fermentation of cellulosic sugars into ethanol. Bioresour. Technol., 214(8): 363-370.

Lynd, L. R., Weimer, P. J., Van Z. W. H. and Pretorius, I. S., 2002, Microbial cellulose utilization: fundamentals and biotechnology. Micro. Mol. Biol. Rev. 
66(3): 506-577.

Miller, G. L., 1959, Use of dinitrosalicylic acid reagent for determination of reducing sugars. Anal. Chem., 31(3): 426-428.

Placido, J., Imam, T. and Capareda, S., 2013, Evaluation of ligninolytic enzymes, ultrasonication and liquid hot water as pretreatments for bioethanol production from cotton gin trash. Bioresour. Technol., 139(7): 203-208.

Shi, J., Mari, S. and. Sharma, R, S., 2008, Microbial pretreatment of cotton stalks by solid state cultivation of Phanerochaete chrysosporium. Bioresour. Technol., 99(14): 65566564.

Shi, J., Sharma, R. S. and Mari S, C., 2009, Microbial pretreatment of cotton stalks by submerged cultivation of Phanerochaete chrysosporium. Bioresour. Technol., 100(19): 43884395.

Silverstein, R. A., Chen, Y., SharmaShivappa, R. R., Boyette, M. D. and Osborne, J., 2007, A comparison of chemical pretreatment methods for improving saccharification of cotton stalks. Bioresour. Technol., 98(16): 3000-3011.

Singh, A., Bajara, S. and Bishnoi, N, R., 2017, Physico-chemical pretreatment and enzymatic hydrolysis of cotton stalk for ethanol production by Saccharomyces cerevisiae. Bioresour. Technol., 244(1): 71-77.

Sluiter, A., Hames, B., Hyman, D., Payne, C., Ruiz, R., Scarlata, C., Sluiter, J., Templeton, D. and Wolfe, J., 2005a, Determination of total solids in biomass and total dissolved solids in liquid process samples. Laboratory Analytical Procedure (LAP). Golden: National Renewable Energy Laboratory.

Sluiter, A., Hames, B., Ruiz, R., Scarlata, C., Sluiter, J. and Templeton, D., 2005b, Determination of ash in biomass. Laboratory Analytical Procedure (LAP). Golden: National Renewable Energy Laboratory.

Sluiter, A., Hames, B., Ruiz, R., Scarlata, C., Sluiter, J., Templeton, D. and Crocker, D., 2008, Determination of structural carbohydrates and lignin in biomass. Laboratory Analytical Procedure (LAP). Golden: National Renewable Energy Laboratory.

Soni, B. and Hass ana, B., 2015, Chemical isolation and characterization of different cellulose nano fibers from cotton stalks. Carbohydr. Polym., 134(12): 581-589.

Tanaka, Y. L., 2006, Ethanol fermentation from biomass resources: current state and prospects. Appl. Micro. Biotechnol., 69(6): 627-642.

Vijayakumar, P., Anantachar, M., Veerangouda, M., Prakash, K. V., Ramachandra, C. T., Nagaraj, M. N., Beladadhi, R. V., Manjunatha, K. and Ramesh, B., 2016, Effect of alkaline pre treatment on solids recovery and delignification of Prosopis juliflora. Eco. Env. Cons. 22: S59-S64.

Zhang, Y. H., 2008, Reviving the carbohydrate economy via multiproduct lignocelluloses biorefineries. J. Ind. Microbiol. Biotechnol., 35(5): 367-375.

\section{How to cite this article:}

Premkumari, M. Veerangouda, Vijayakumar Palled, M. Anantachar, Sharanagouda Hiregoudar, Nagaraj M. Naik and Beladadhi, R.V. 2019. Effect of Potassium Hydroxide (KOH) Pretreatment on Solids Recovery, Delignification and Total Sugars of Cotton Stalk. Int.J.Curr.Microbiol.App.Sci. 8(02): 2457-2467. doi: https://doi.org/10.20546/ijcmas.2019.802.286 